\title{
Peran Komite Sekolah Terhadap Kepemimpinan Kepala Sekolah
}

\author{
${ }^{1}$ Silvia Ulfaturrahmi, ${ }^{2}$ Agus Ramdani, ${ }^{3}$ A. Hari Witono \\ ${ }^{1,2,3}$ Program Studi Magister Administrasi Pendidikan, Universitas Mataram, Indonesia \\ Email Korespondensi: silviaulfa137@gmail.com
}

\begin{abstract}
Abstrak. Penelitian ini bertujuan untuk Mendiskripsikan peran komite sekolah sebagai badan pemberi pertimbangan, terhadap kepemimpinan kepala sekolah di TK Doremi Mataram Kecamatan Selaparang. Pendekatan penelitian ini menggunakaan kualitatif dalam bentuk studi kasus. Sumber data ada dua yaitu data primer dan data sekunder. Data primer diperoleh dari informan. Data sekunder bersumber dari dokumen resmi yang ada dalam bentuk catatan, gambar, foto dan bahan lain yang dapat mendukung penelitian ini. Prosedur pengumpulan data adalah: (1) wawancara terstruktur, (2) observasi, dan (3) studi dokumen. Analisis data dilakukan dengan beberapa tahapan yaitu reduksi data, penyajian data, dan penarikan kesimpulan. Pemeriksaan keabsahan data dalam penelitian ini meliputi empat tehnik yaitu uji kredibilitas, uji transferabilitas, uji dependabilitas, dan uji konfirmabilitas. Berdasarkan hasil penelitian menujukkan bahwa tidak ada peran serta komite dalam memberikan pertimbangan terhadap penerimaan dan pengelolaan peserta didik. Penerimaan dan pengelolaan peserta didik diatur sendiri oleh pihak sekolah, mulai dari menentukan metode dan kegiatan yang dilakasnakan dengan memperhatikan kebutuhan dan perkembangan anak usia dini.
\end{abstract}

Kata kunci: Komite Sekolah; Kepemimpinan Kepala Sekolah; Deskriptif.

\section{PENDAHULUAN}

Kepala sekolah sebagai manajer pendidikan dituntut bertanggungjawab atas seluruh komponen sekolah (Barr \& Salmarsh, 2014). Kepala sekolah harus berupaya meningkatkan mutu pendidikan yang berorientasi kepada pemakai, baik internal (siswa), maupun eksternal (Komite Sekolah / masyarakat), pemerintah, maupun dunia industry, dunia usaha dan menciptaan iklim kondusif bagi terwujudnya perubahan serta pengembangan sekolah (Cook, 2014).

Menurut Ryan (2010), sekolah yang efektif, bermutu dan favorit tidak lepas dari peran seorang kepala sekolahnya. Kepemimpinan kepala sekolah memerlukan perhatian yang utama karena melalui kepemimpinan yang baik, diharapkan lahirnya tenaga-tenaga yang berkualitas dalam berbagai bidang sebagai pemikir, pekerja, yang terpenting bahwa melalui pendidikan (Cheng \& Szeto, 2016).

Kepemimpinan kepala sekolah tidak akan bisa berjalan sendiri tanpa adanya dukungan dari berbagai pihak. Dari sinilah peran dan partisipasi masyarakat sangat diperlukan sehingga dapat mendukung peningkatan kualitas pendidikan (Truong, et al., 2017). Sebagai realisasi dari peran serta masyarakat di bidang pendidikan, diperlukan suatu wadah yang dapat mengakomodasi pandangan, aspirasi, dan menggali potensi masyarakat untuk menjamin terciptanya demokratisasi, transparasi, dan akuntabilitas pendidikan. Salah satu wadah tersebut adalah dengan adanya Dewan Pendidikan ditingkat Kabupaten/Kota dan Komite Sekolah di tingkat satuan pendidikan (Rohayati, et al., 2014).

Sinergi antara sekolah dan komite sekolah menyebabkan tanggung jawab pendidikan menjadi tanggung jawab bersama. Akan tetapi pada kenyataannya peran komite sekolah sebagai mitra sekolah belum memaksimalkan perannya (Ramadhani \& Kardoyo, 2019). Komite sekolah yang menjadi perwakilan dari orangtua/wali dan masyarkat yang perduli terhadap pendidikan, pada kenyataannya belummenjalankan tugasnya dengan baik. Menurut penelitian Ramadhani \& Kardoyo (2019) menunjukkan bahwa tingkat partisipasi masyarakat dan orangtua peserta didik dalam mendukung penyelenggaraan pendidikan disekolah hanya berada di rata-rata $57,10 \%$. Hasil tersebut menunjukkan bahwa keberadaan peran komite sekolah belum 
maksimal dalam mengkolaborasikan aspirasi masyarakat terhadap sekolah atau pendidikan.

Berdasarkan hasil observasi awal yang telah dilakukan dengan Kepala TK Doremi Mataram dan Ketua Komite Sekolah pada tanggal 01 November 2019 diperoleh bahwa telah terlaksana peran orangtua di TK Doremi. Komite sekolah berpartisipasi dalam pelaksanaan program-program yang direncanakan oleh TK Doremi, baik dalam bidang akademik maupun bidang nonakademik.

Hal ini terbukti dari tahun ketahun prestasi TK Doremi Mataram semakin meningkat, selain itu peserta didik juga mengalami kenaikan yang signifikan, dengan jumlah yang setiap tahun semakin bertambah, semua itu terjadi karena adanya kerjasama dengan komite sekolah, akan tetapi beberapa program kerja yang dilaksanakan belum bisa berjalan dengan optimal. Permasalahan tersebut disebabakan karena pihak sekolah kurang memahami akan pentingnya perencanaan dan pengelolaan berbagai hal yang dibutuhkan untuk mencapai tujuan, seperti halnya pendanaan yang melebihi dari perencanaan, serta kegiatan belajar yang tidak efektif, sehingga akan berdampak pada hasil capaian TK Doremi.

Upaya dalam menciptakan hubungan yang sinergis, kepala sekolah harus memberikan kesempatan terhadap komite sekolah untuk melakasanakan perannya. Penelitian yang dilakukan oleh Hasbullah (2010) menjelaskan bahwa adanya hubungan sinergis antara komite dan sekolah yang dapat menumbuhkan rasa tanggung jawab bersama antara sekolah dengan masyarakat sebagai mitra kerja untuk membangun pendidikan, dari sini masyarakat akan bisa menyalurkan segala bentuk aspirasi terhadap pendidikan. Sejalan dengan hal tersebut Mulyasa (2012) menyatakan bahwa keterlibatan komite sekolah dapat mewujudkan visi dan misi sekolah, dengan memberikan masukanmasukan terhadap penyusunan program secara relevan. Jalinan tersebut dapat terjadi jika kepala sekolah secara aktif membangun hubungan yang saling menguntungkan.
Hubungan sekolah dengan masyarakat sebagai suatu proses menumbuhkan rasa saling pengertian kepada masyarakat dan orang tua murid tentang visi dan misi sekolah, program kerja sekolah, masalah - masalah yang dihadapi serta berbagai aktivitas sekolah lainnya. Suatu lembaga pendidikan didirikan karena didorong oleh kebutuhan masyarakat, sehingga tanggung jawab pendidikan di sekolah merupakan tanggung jawab masyarakat, keluarga, dan pemerintah. Hasil penelitian Kiprono, et al (2015) menjelaskan bahwa pentingnya kemitraan sekolah dalam pengembangan sektor pendidikan, dengan berdasarkan pengalaman diberbagai negara menunjukkan bahwa sekolah berfungsi lebih baik dalam pendidikan, terutama dengan keterlibatan orangtua secara aktif dalam perencanaan dan pengeloaan. Kegiatan sekolah di Indonesia misalnya pada tahun 2010 masyarakat setempat telah menyumbang sekitar 2,6 juta dalam kontribusi secara materi maupun nonmateri untuk memfasiltitasi pelakasanaan rencana pengembangan sekolah melalui partisipasi komite sekolah (Yasin \& Lisdawati, 2017).

Partisipasi masyarakat terhadap lingkungan sekitar ini semakin dirasakan penting pada masyarakat karena telah menyadari dan memahami akan pentingnya sebuah pendidikan. Keterbatasan pemerintah dalam pengadaan sarana dan prasarana, serta pembiayaan pendidikan, menyebabkan dukungan serta partisipasi masyarakat menjadi semakin penting, terutama masyarakat yang terkait langsung dengan sekolah yang bersangkutan dalam rangka meningkatkan kualitas pendidikan. Penelitian ini bertujuan untuk Mendiskripsikan peran komite sekolah sebagai badan pemberi pertimbangan, terhadap kepemimpinan kepala sekolah di TK Doremi Mataram Kecamatan Selaparang.

\section{METODE PENELITIAN}

Penelitian ini menggunkaan pendekatan kualitatif dengan metode studi kasus. Penelitian kualitatif mengunakan metode pengumpulan data dengan teknik wawancara, observasi dan dokumentasi (Ulfatin: 2017). Penelitian ini berkaitan tentang peran komite 
sekolah dalam kepemimpinan kepala sekolah yang akan dikaji dengan menggunakan pendekatan fenomenologi, sebab dalam penelitian ini memerlukan penghayatan dan interpretasi terhadap peran serta komite sekolah.

Sumber data dalam penelitian ini dikelompokan menjadi dua yaitu, sumberdata primer dan sumber data sekunder. Sumber data primer adalah pernyataan dan tindakan ornag yang diamati atau diwawancara yang direkam melalui catatn tertulis dan pengambilan foto. Sedangkan data sekunder adalah data yang berupa dokumen, foto atau catatan lain yang menunjang informasi dari informan (Moleong, 2014). Data primer diperoleh dari informan yaitu komite sekolah, kepala sekolah, wakil kepala sekolah, wakil kepala sekolah, pegawai tata usaha, guru kelas, orag tua siswa, dan satpam. Data sekunder bersumber dari dokumen resmi yang ada dalam bentuk catataan, arsip, gambar, dan bahan lain yang berkaitan dengan penelitian ini. Penelitian ini menngunakan pengumpulan data dengan teknik wawancara terstruktur, observasi partisipatif, dan analisis dokumen.

Miles dan Huberman (1992) menyatakan bahwa analilis pengumpulan data dapat dilakukan selama dan sesudah selesai dilapangan secara terus menerus sampai tuntas. Penelitian ini menngunkan teknik analisis data sesudah di lapangan dengan teknik analisis data interaktif sehingga data yang diperoleh jenuh, artinya tidak ada perbeaan infoemasi dari informan ynag satu dengan yang lian dan dengan teknik satu dengan teknik yang lain. Adapun proses analissi data yang dilakukan menliputi reduksi data, penyajian data dan penarikan kesimpulan. Adapun untuk menguji keabsahan data pada enelitian ini menggunakan empat langkah uji kredibiltas data yaitu uji kredibilitas, mencakup triangulasi, perpanjanan pengamatan, diskusi dengan teman sejawat dan member chek; uji teransferabilitas, uji dependabilitas dan uji konfirmabilitas.

HASIL DAN PEMBAHASAN

Peran Komite Sekolah Sebagai Pemberi Pertimbangan

Jurnal Ilmu Sosial dan Pendidikan
Komite sekolah sebagai badan pemberi pertimbangan dalam menentukan pelaksanaan kebijakan pada satuan pendidikan yang berperan memberikan kekuatan dan pendorong terbentuknya sekolah yang berkualiatas. Kualitas sekolah menjadi salah satu parameter dalam usaha peningkatan kualitas dan percepatan yang harus dilakukan secara terus menerus.

\section{Kebijakan dan Program Pendidikan}

Kebijakan yang ada di TK DOREMI Mataram disusun sebagai tolak ukur dalam mengarahkan para anggota sekolah dan masyarakat untuk melaksanakan kegiatankegiatan sekolah sehingga dapat mencapai tujuan yang telah ditetapkan. Untuk mencapai keberhasilan pada program sekolah tidak terlepas dari kerjasama yang terjalin antara kepala sekolah, guru, staf, dan komite.

Kepala sekolah TK DOREMI Mataram menjelaskan, sebelum memberikan kebijakan terhadap program-program sekolah yang akan dilakukan, terlebih dahulu menjalin komunikasi dengan mengadakan rapat rutin yang dilaksanakan setiap 1 (satu) bulan sekali untuk membahas sejauhmana perkembangan kegiatan sekolah. Pada rapat rutin tersebut pihak sekolah dan beberapa ketua forum kelas yang telah ditunjuk sebagai perwakilan dari komite sekolah, membahas terkait dengan kegiatan sekolah yang akan dilaksanakan dengan meminta masukan para anggota komite sekolah sekiranya apa saja kegiatan yang perlu dilaksanakan dan mengevaluasi kegiatan yang telah terlaksana, seperti yang disampaikan pada saat wawancara kepala sekolah sebagai berikut:

"iya bisa dikatakan seperti itu, sebelum menentukan kebijakan terhadap beberapa program-program sekolah kami mengadakan rapat terlebih dahulu yang dilakukan setiap 1 (satu) bulan sekali dengan beberapa ketua forum kelas yang telah ditunjuk sebagai perwakilan dari anggota komite sekolah, yang bertujuan untuk mengkomunikasikan sekiranya apa saja masukan yang diberikan dalam menetukan program kerja yang akan diaksanakan dan mengevaluasi kegiatan yang 
telah terlaksana." (W/Kepala Sekolah/ No.1.1/ 5 Agustus 2020).

Hal serupa disampaikan oleh ketua komite sekolah sebagai berikut:

"iya, komite sekolah memberikan pertimbangan terhadap program rutin tahunan yang dijalankan sekolah, seperti: kids performance day, family day, outing class, sport day, dan pentas seni di akhir semester" (W/ Ketua komite sekolah/ No.1.1/ 6 Agustus 2020).

Informasi diperjelas kembali dengan pernyataan salah satu anggota komite sekolah sebagai berikut:

"iya begitulah, mau ndak mau komite sekolah memberi pertimbangan hal tersebut disepakati juga oleh kepala sekolah, karena setau saya selama bergabung menjadi anggota komite dan dilibatkan sebagai kepanitian dalam kegiatan inti TK DOREMI. Kami komite sekolah dilibatkan dalam memberi pertimbangan baik program maupun kebijakan" (W/Komite Sekolah/ No.1.1/ 12 Agustus 2020).

Hal tersebut disampaikan juga oleh beberapa guru di TK DOREMI Mataram sebagai berikut:

"iya jelas, komite sekolah memberikan pertimbangan dengan program sekolah yang akan dijalani” (W/ Guru Sentra/ No.1.1/7 Agustus 2020). Hal yang sama diperkuat kembali, "iya tentu, komite sekolah berperan aktif dalam memberikan masukan terhadap berbagai macam program sekolah yang akan dilakukan" (W/Guru Kelas/ No.1.1/10Agustus 2020).

Kebijakan serta program kerja di TK DOREMI Mataram disusun berdasarkan pertimbangan dari kepala sekolah maupun komite. Perencanaan dan pelaksankan kegiatan sekolah ditentukan sesuai dengan hasil rapat rutin yang dilakukan oleh pihak sekolah dan komite. Adapun beberapa kegiatan tahunan yang dilaksanakan di TK DOREMI Mataram seperti: kids performance day, family day, outing class, sport day, dan pentas seni di akhir semester.

Program-program kerja sekolah di TK DOREMI Mataram ditentukan berdasarkan keputusan bersama dengan melakukan koordinasi dengan komite sekolah, guru beserta staf. Sehingga dapat disimpulkan bahwa komite sekolah menyepakati apa yang diputuskan oleh kepala sekolah.

\section{Rencana dan Anggaran Pendidikan}

Rencana Pendapatan dan Belanja Sekolah (RAPBS) adalah salah satu acuan dalam manajemen sekolah dengan adanya RAPBS inilah semua kegiatan sekolah dapat direncanakan, baik secara teknis maupun nonteknis. Dana yang didapatkan pihak sekolah untuk pelaksanaan program diatur sedemikian rupa sehingga penggunaannya jelas dan terbuka. Hal tersebut bertujuan untuk melatih keterbukaan terhadap dana pendidikan yang dikelola khususnya di TK DOREMI Mataram.

Kepala sekolah TK DOREMI Mataram menjelaskan tentang pengelolaan anggaran dana belanja sekolah. Terkait pengelolaan dana tersebut dilakukan rapat rutin sesuai kesepakatan bersama dengan anggota komite sekolah yang membahas program yang akan dilakukan dan tahap evaluasi terhadap beberapa program yang telah terlaksana. Karena pada instansi swasta pendanaannya tidak terlepas dari peran aktif orangtua peserta didik untuk ikut serta dalam memberikan kontribusi demi kelancaran program sekolah. Seperti yang telah disampaikan pada wawancara dengan kepala sekolah sebagai berikut:

"iya, untuk anggaran dana sekolah kami melibatkan komite sekolah dengan mengkomunikasikan bersama sekiranya seberapa banyak pengeluaran biaya dari program yang akan dilakukan, hal tersebut disampaikan pada setiap rapat rutin yang dilakukan dengan komite sekolah. Kan pembiayan disekolah negeri dan swasta berberda ya, kami sekolah swasta tidak terlepaslah dari peran serta orangtua murid untuk memberikan kontribusinya terhadap pengadaan anggaran kegiatan 
sekolah" (W/Kepala Sekolah/ No.1.2/ 5 Agustus 2020).

Perencanaan dan pengelolaan dana kegiatan sekolah di TK DOREMI Mataram tidak terlepas dari peran serta komite sekolah. Setiap kegiatan sekolah mulai dari penyusunan RAB (Rencana Anggaran Belanja) sampai pada pengadaan dana, kepala sekolah selalu melibatkan komite, sehingga program dan pendanaan lebih transparan. Hal tersebut disampaikan pada wawancara dengan ketua komite sekolah sebagai berikut:

"iya, komite sekolah ikut serta dalam pengelolaan anggaran dana sekolah demi kelancaran kegiatan, kami dilibatkan mulai dari penyusunan RAB (Rencana Anggaran Belanja) sampai pada pengadaan dana" (W/Komite Sekolah/ No.1.2/ 10 Agustus 2020).

Pernyataan yang sama disampaikan juga oleh anggota komite sekolah sebagai berikut:

"ohh kalau ini ya tentu, kami dari komite sekolah ikut menentukan perencanaan anggaran belanja sekolah, dengan melakukan koordinasi sehingga pendanaan yang dibutuhkan lebih jelas, ini perlu dilakukan dalam manajemen sebagai acuan kegiatan atau program-program yang akan di jalankan di sekolah. Sehingga perlu kejelasan pada setiap aspek yang akan di tangani dalam kegiatan sekolah" (W/Komite Sekolah/ No.1.2/ 12 Agustus 2020)..

Anggaran pada setiap kegiatan yang terlaksana berkaitan dengan proses belajar mengajar, tidak terlepas dari peran komite sekolah dalam memberikan kontribusinya, hal tersebut terlihat ketika diawal pembelajaran peserta didik tahun ajaran 2020-2021, pihak komite melakukan evaluasi terkait dengan pengadaan dana ATK. Pengadaan dana ATK dimasa pendemi dengan sistem online seperti ini berbeda dengan tahun-tahun sebelumnya, untuk pembiayaan ATK bisa dikurangi dengan memanfaatkan ATK sebelumnya yang masih layak pakai dengan menyesuaikan kebutuhan masing-masig kelas, mulai dari kelas Play
Group hingga TK, supaya penggunaan dana lebih efektif dan efisien. Hal tersebut disampaikan pada wawancara dengan salah satu guru di TK DOREMI Mataram sebagai berikut:

"iya, komite sekolah ikut berperan memberikan masukan dan kontribusi terhadap pendanaan program sekolah, seperti pada rapat awal tahun pembelajaran komite sekolah memberikan masukan, untuk pengadaan dana ATK biar lebih dikurangi untuk pengeluarannya karena sistem pembelajaran berbeda dengan tahun-tahun sebelumnya, yang tahun ini dilaksanakan secara online sehingga pengeluarannyapun tidak terlalu banyak. Pengadaan ATK biar masingmasing orangtua yang menyediakan sendiri dengan menggunakan ATK sebelumnya yang masih layak pakai, sehingga bisa lebih efektif dan efisien" (W/Guru Kelas/ No.1.2/ 10 Agustus 2020).

Perencanaan anggaran dana pendidikan di TK DOREMI Mataram tidak terlepas dari keterlibatan komite sekolah yang ikut memberikan masukan dan kontribusi demi kelancaran kegiatan sekolah, mulai dari penyusunan $\mathrm{RAB}$ dan pengadaan dana sehingga program ataupun dana yang ada disekolah menjadi lebih transparan. Maka dapat disimpulkan bahwa komite sekolah menjalankan perannya sebagai badan pemberi pertimbangan.

\section{Kriteria Tenaga kependidikan}

Pada manajemen ketenagaan di sekolah bertujuan menata para anggota sekolah untuk mengembangkan keahlian demi perkembangan karir. Guru dan pegawai itu sendiri harus memiliki kematangan dalam sosial dan emosional sehingga dapat menjalin interaksi yang bagus dengan siswa. Beberapa kriteria tenaga kependidikan yang harus dimiliki untuk mengabdi di TK DOREMI Mataram diantaranya, minimal kualifikasi S1 (strata 1), sayang anak-anak, dan memiliki keahlian dalam berinteraksi dengan anak-anak. 
Kepala sekolah TK DOREMI Mataram menjelaskan tentang kriteria tenaga kependidikan, hal tersebut lebih kepada menguasai metode belajar sambil bermain yang diterapkan pada pendidikan anak usia dini. Kriteria tenaga kependidikan ditentukan oleh pihak sekolah khususnya yang lebih tau apa saja yang diperlukan untuk pengembangan peserta didik. Penjelasan tersebut disampaikan pada wawancara dengan kepala sekolah TK DOREMI Mataram sebagai berikut:

"tidak ada keterlibatan komite sekolah dalam menentukan kriteria tenaga kependidikan, karena yang lebih tau ya kami dari pihak sekolah, dalam penerimaan pendidik maupun tenaga pendidik, untuk seleksinyapun saya sendiri dan salah satu guru kelas yang langsung mewawancarai. Kriteria yang diperlukan untuk mengabdi di TK DOREMI Mataram antara lain: minimal kualifikasi S1 (strata 1), sayang anakanak, dan memiliki keahlian dalam berinteraksi dengan anak-anak" (W/Kepala Sekolah/ No.1.3/ 5 Agustus 2020).

Hal serupa disampaikan pada wawancara dengan ketua komite sekolah sebagai berikut:

"tidak, karena hal tersebut merupakan ranah internal lembaga, sehingga komite sekolah tidak dilibatkan" (W/Ketua Komite Sekolah/ No.1.3/ 6 Agustus 2020).

Kriteria tenaga kependidikan di TK DOREMI Mataram tidak memiliki kriteria khusus, akan tetapi ada beberapa komponen yang harus diperhatikan untuk mendukung keberhasilan dalam pendidikan anak usia dini, seperti halnya pandai menciptakan suasana yang nyaman dan aman sebagai penyemangat peserta didik dalam belajar. Keterlibatan komite sekolah dalam penentuan kriteria tenaga kependidikan tidak ada dalam hal ini, karena yang lebih tau kebutuhan peserta didik pihak sekolah sendiri. Komite hanya memberikan masukan-masukan dalam proses pembelajaran saja. Pernyataan tersebut disampaikan pada wawancara dengan salah satu guru di TK DOREMI Mataram sebagai berikut:

"tidak sih, untuk kriteria tenaga kependidikannya yang menentukan pihak sekolah saja. Untuk proses pembelajarannya barulah komite sekolah dilibatkan untuk memberikan masukanmasukan demi kelancaran kegiatan pembelajaran" (W/ Guru Kelas/ No.1.3/ 10 Agustus 2020).

Begitu juga yang dijelaskan pada saat wawancara dengan anggota komite sekolah sebagai berikut:

"Tidak memberikan pertimbangan sih hanya memberikan saran, karena kami dari komite sekolah ada tugas khususnyalah, bahwa kriteria yang ini harus di tetapkan misalnya melihat kekurangan guru, kemudian komite sekolah mengajukan permohonan kepada kepala sekolah suapaya diperbaiki sebagai tahapan evaluasi sekolah, fungsinya disini hanya memberikan saran-saran, kepada kepala sekolah ada keluhan di masyrakat tentang guru yang bersangkutan jadi peranannya, tidak terlalu banyak, memberikan pertimbangan, terhadap kriteria tenaga kependidikan" (W/ Komite Sekolah/ No.1.3/ 12 Agustus 2020).

Selain dalam proses pembelajaran, komite sekolah juga memberikan masukan jika kurangnya tenaga kependidikan untuk menambah tenaga kependidikan. Hal tersebut terlihat ketika komite memberikan saran ke kepala sekolah untuk menambah guru pendamping, sehingga bisa leluasa mengawasi peserta didik ketika belajar mau bermain. Pernyataan tersebut dijelaskan saat wawancara dengan salah satu guru di TK DOREMI Mataram sebagai berikut:

"komite sekolah berhak memberikan saran kepada kepala sekolah, untuk menambah guru pendamping, tetapi saran tersebut tidak bisa teralisasi karena kembali ke persoalan pendanaan yang sangat terbatas, untuk menggaji guru tetap pun sudah kewalahan, karena memperoleh dana tambahan itu juga sangat susah. Pada 
umumnya berdasar dana BOP (Biaya Operasional Pendidikan) disesuaikan dengan jumlah murid dan kebutuhan sekolah, sehingga untuk memenuhi kekurangan guru untuk mengangkat tenaga honorer sangat susah, karena dana yang di terima tidak sesuai dengan program kerja" (W/ Guru Kelas KB/ No.1.3/ 13 Agustus 2020)..

Keriteria tenaga kependidikan di TK DOREMI Mataram ditentukan sendiri oleh pihak sekolah, sesuai kriteria tenaga pendidik pendidikan anak usia dini, dalam hal ini dapat disimpulkan bahwa tidak ada keterlibatan komite sekolah dalam memberi pertimbangan dalam penyeleksiannya. Komite sekolah hanya dapat memberikan masukan-masukan untuk pembelajaran saja, akan tetapi tetap dengan pertimbangan dari kepala sekolah.

\section{Kriteria Fasilitas Pendidikan}

Fasilitas pendidikan atau sarana dan prasarana yang terdapat disekolah, sebagai salah satu penunjang dalam pelaksanaan pembelajaran peserta didik, dengan tersedianya fasilitas dapat mempermudah pendidik untuk melaksanakan proses belajar mengajar disekolah.

Kepala sekolah TK DOREMI Mataram menjelaskan tentang sarana dan prasarana yang menunjang proses pembelajaran disekolah. Lingkungan sekolah pendidikan anak usia dini lebih diperhatikan pada kebersihan serta kenyamanan bagi peserta didik, dengan menyediakan tempat bermain dan belajar yang luas, terjangkau, serta aman. Kriteria fasilitas pendidikan yang ada disekolah tidak terlepas dari peran komite sekolah dengan memberikan beberapa masukan-masukan demi kelancaran pembelajaran. Seperti yang telah disampaikan pada wawancara dengan kepala sekolah TK DOREMI Mataram sebagai berikut:

"Iya, Komite sekolah berperan dalam memberikan pertimbangan terhadap pengadaan sarana dan prasarana dengan memberikan masukan-masukan, seperti halnya pada penyediaan APE (Alat Permainan Edukasi) yang sesuai, jika ada fasilitas kelas AC yang bocor atau bermasalah segera untuk diperbaiki, dan selama pendemi Covid19 pihak komite memberikan masukan dengan sosialiasasi penggunaan aplikasi online yang tepat digunakan untuk pembelajaran anak usia dini seperti: Google Meet, dan zoom" (W/Kepala Sekolah/ No.1.4/ 10 Agustus 2020).

Begitu juga yang disampaikan pada wawancara dengan ketua komite sekolah TK DOREMI Mataram sebagai berikut:

"iya, kami dari komite sekolah memberikan pertimbangan terhadap penyediaan sarana dan prasarana disekolah, hal tersebut disampaikan melalui kepala sekolah saat rapat bulanan, sekiranya apa saja yang perlu diganti atau diperbaiki baik itu terhadap pengadaan APE, perlengkapan kelas ataupun tempat bermain anak" (W/Ketua Komite Sekolah/ No.1.4/ 6 Agustus 2020)

Kriteria fasilitas pendidikan yang ada di TK DOREMI Mataram tidak terlepas dari peran komite sekolah dalam memberikan pertimbangan terhadap pengadaan sarana dan parasana, berupa fasilitas belajar, bermain, penggunaan APE, hingga pengadaan ATK. Karena dari komite sekolah sendiri sangat memperhatikan efektif dan efisiennya apalagi dalam pembelajaran saat ini yang dilaksanan secara online, untuk mengurangi pengeluaran pada pengadaan ATK, Pihak komite sekolah menyarankan kepala sekolah untuk meniadakan pembayaran ATK, dengan alasan menggunakan ATK sebelumnya yang masih layak pakai sehingga dapat mengurangi pengeluaran orang tua peserta didik. Pernyataan tersebut disampaikan saat wawancara dengan anggota komite sekolah sebagai berikut:

"Iya, memberi pertimbangan terhadap fasilitas yang ada, misalnya pada pengadaan APE selama pembelajaran secara online gini, komite sekolah memberikan masukan terhadap sekolah dengan menyediakan APE sesuai kebutuhan dengan memperhatikan efektif 
dan efisiennya ya, seperti ATK tidak perlu disediakan dari sekolah, cukup menggunakan ATK yang ada dirumah karena kami dari orangtua secara keseluruhan punya dirumah. Sehingga pengeluaran dana tidak banyaklah" (W/ Komite Sekolah/ No.1.4/ 12 Agustus 2020).

Hal serupa disampaikan juga pada wawancara dengan salah satu guru TK DOREMI Mataram sebagai berikut:

"iya bisa dibilang seperti itu, komite sekolah memberikan pertimbangan pada setiap kegiatan yang dilakukan sekolah, selalu dikomunikasikan dengan komite sekolah termasuk dalam hal sarana dan prasarana, demi kelancaran kegiatan sekolah" (W/ Guru Kelas No.1.4/ 10 Agustus 2020).

Pernyataan tersebut diperjelas kembali saat wawancara dengan salah satu guru di TK DOREMI Mataram:

"Memberikan pertimbangan karena setiap ada kegiatan ada ketentuan dari rencana anggaran biaya sekolah tentang pengadaan APE, ATK, perlengkapan kelas ataupun tempat bermain anak, nah itu disitulah kita memasukan setiap kegiatan dan dan melakukan koordinasi dengan komite, jadi tidak mungkin terlaksana tanpa ada persetujuan dari komite" (W/Guru Kelas KB/ No.2.1/ 13 Agustus 2020).

Fasilitas pendidikan yang tersedia di TK DOREMI Mataram tidak terlepas dari peran komite sekolah dalam memberikan pertimbangan terhadap pengadaan sarana dan prasarana yang disekolah, demi kelancaran kegiatan program sekolah, hal tersebut selalu dikomunikasikan pada rapat bulanan yang disampaikan melalui kepala sekolah.

\section{Penerimaan dan Pengelolaan Peserta Didik}

Peserta didik adalah subjek terpenting pada suatu instansi, begitu juga dengan lembaga pendidikan anak usia dini. Pada pengelolaan peserta didik berkaitan dengan segala bentuk aktivitas, mulai dari masuknya, pertumbuhan dan perkembangan dalam proses pembelajaran, hingga lulus dari sekolah.

Kepala sekolah TK DOREMI Mataram menjelaskan tentang penerimaan dan pengeloaan peserta didik. Partisipasi komite sekolah tetap ada dengan memberikan masukan-masukan terhadap kegiatan yang dilaksanakan sekolah, akan tetapi pada penerimaan dan pengelolaan peserta didik, pihak sekolah yang menentukan sendiri, mulai dari memilih metode dan kegiatan-kegiatan yang sesuai dengan perkembangan anak usia dini.

Penjelasan tersebut disampaikan pada wawancara dengan kepala sekolah TK DOREMI Mataram sebagai berikut:

"tidak ada peran komite sekolah dalam hal ini, karena khusus penerimaan dan pengelolaan peserta didik, pihak sekolah yang menentukan sendiri, mulai dari pemilihan metode, kegiatan-kegiatan yang sesuai dengan perkembangan anak usia dini” (W/Kepala Sekolah/ No.1.5/ 5 Agustus 2020).

Hal serupa dipertegas kembali dengan pernyataan salah satu guru TK DOREMI Mataram, berdasarkan hasil wawancara sebagai berikut:

"tidak ada pertimbangan dari komite sekolah dalam hal ini, karena dalam penerimaan dan pengelolaan peserta didik, pihak sekolah yang mengatur sendiri" (W/Guru Kelas/ No.1.5/ 10 Agustus 2020).

Kontribusi komite sekolah dalam penerimaan dan pengelolaan peserta didik, tidak terlalu banyak dalam hal ini karena merupakan ranah internal sekolah, komite hanya meberikan saran-saran untuk prekrutan peserta didik dengan menggunakan metode yang lebih menarik dan disesuaikan dengan masa digital yaitu secara online menampilkan video kegiatan pada sosial media dan website sekolah, sehingga memudahkan dalam memperkenalkan profil sekolah secara umum. Pernyataan tersebut dijelaskan saat wawancara dengan anggota komite sekolah: 
"Dalam hal ini kami dari komite sekolah tidak terlibat dalam peneriman dan pengelolaan peserta didik karena itu ranah internal ya, komite sebatas memberikan saran tentang penggunakan aplikasi online mengikuti era digital untuk mempromosikan profil sekolah, sehingga dapat menarik minat masyarakat sekitar untuk menyekolahkan anak-anak mereka di TK DOREMI Mataram" (W/Ketua Komite Sekolah/ No.1.4/ 12 Agustus 2020).

Berdasarkan hasil wawancara tersebut, dapat disimpulkan bahwa tidak ada peran serta komite dalam memberikan pertimbangan terhadap penerimaan dan pengelolaan peserta didik. Penerimaan dan pengelolaan peserta didik diatur sendiri oleh pihak sekolah, mulai dari menentukan metode dan kegiatan yang dilakasnakan dengan memperhatikan kebutuhan dan perkembangan anak usia dini.

\section{KESIMPULAN}

Peran komite sekolah sebagai badan pemberi pertimbangan, terhadap kepemimpinan kepala sekolah di TK DOREMI Mataram Kecamatan Selaparang, telah berjalan sebagaimana yang diharapkan, akan tetapi belum optimal. Peran komite sekolah dapat terlihat dalam memberi pertimbangan terhadap kebijakan dan program yang dijalankan. Hal tersebut terpenuhi karena kepala sekolah melakukan koordinasi terlebih dahulu sebelum menentukan kegiatan sekolah, sehingga komite sekolah ikut menyepakati apa yang menjadi keputusan pihak sekolah.

Selanjutnya tentang rencana dan anggaran pendidikan, komite sekolah berperan dalam memberikan pertimbangan, karena pihak sekolah selalu melakukan rapat rutin untuk membahas kegiatan sekolah yang akan dijalankan, seperti halnya pada anggaran yang diperlukan, komite sekolah menjalin kerjasama dengan intansi terkait untuk pengadaan bantuan biaya kegiatan, dengan mengajukan proposal dan mencari sponsor yang dapat mendukung kegiatan beruapa bingkisan.

Begitupula dengan fasilitas yang ada di sekolah, hal tersebut tidak terlepas dari peran komite sekolah dalam memberikan pertimbangan, dengan memberikan masukanmasukan pada pihak sekolah terkait sarana prasana, pengadaan APE yang sesuai dengan kebutuhan peserta didik sehingga kegiatan sekolah dapat berjalan lancar. Akan tetapi pada penentuan kriteria tenaga pendidik dan pengelolaan peserta didik, komite sekolah tidak berperan sepenuhnya, karena itu merupakan tanggung jawab penuh sekolah yang lebih paham tentang kebutuhan peserta didik.

\section{SARAN}

a. Koordinasi antara komite sekolah, kepala sekolah, guru, dan pegawai diharapkan lebih meningkat, sehingga dalam pelaksanaan peran komite sekolah terhadap penyelenggaraan pendidikan terlaksana sesuai dengan yang diharapkan.

b. Sekolah harus mendukung komite sekolah dalam melaksanakan perannya dalam penyelenggaraan pendidikan.

\section{DAFTAR PUSTAKA}

Barr, J., \& Saltmarsh, S. (2014). "It all comes down to the leadership" The role of the school principal in fostering parent-school

engagement. Educational

Management Administration \& Leadership, 42(4), 491-505.

Cheng, A. Y., \& Szeto, E. (2016). Teacher leadership development and principal facilitation: Novice teachers' perspectives. Teaching and Teacher Education, 58, 140148.

Cook, J. W. (2014). Sustainable School Leadership: The Teachers' Perspective. International Journal of Educational Leadership Preparation, 9(1).

Hasbullah. (2010). Otonomi Pendidikan. Jakarta: Rajawali Press.

Kiprono, F. J., Nganga, M., \& Kanyiri, J. (2015). An Assessment of School Management Committees Capacity in the Implementation of FPE Funds in Public Primary Schools: A survey 
of Eldoret East District, Kenya. International Journal of Education and Research, 3(1), 243.

Miles, M. B \& Huberman, A. M. (1994). Qualitative Data Analysis: Asourcebook Of New Metohods. Terjemahan Rohidi, T.R. Jakarta: UI Press.

Moleong, L. J. (2015). Metode PenelitianKuelitatif. Bandung: Remaja Rosdakarya.

Mulyasa. (2012). Manajemen dan Kepemimpinan Kepala Sekolah. Jakarta: Bumi Aksara.

Ramadhani, N. S., \& Kardoyo, K. (2019). Kepemimpinan Kepala Sekolah, Biaya Pendidikan, Komite Sekolah, Perilaku Organisasi Terhadap Mutu Lulusan Melalui Mutu Proses. Economic Education Analysis Journal, 8(2), 713-730.

Rohayati, T., Sudjarwo, S., \& Rini, R. (2014). Pengaruh Kepemimpinan Kepala Sekolah Dan Peran Komite Sekolah Terhadap Kinerja Guru. Jurnal Manajemen Mutu Pendidikan, 2(3).

Ryan, J. (2010). Establishing inclusion in a new school: The role of principal leadership. Exceptionality

Education International, 20(2), 624.

Truong, T. D., Hallinger, P., \& Sanga, K. (2017). Confucian values and school leadership in Vietnam: Exploring the influence of culture on principal decision making. Educational Management Administration \& Leadership, 45(1), 77-100.

Ulfatin, N. (2017). Metode Peneitian Kualitatif di Bidang Pendidikan: Teori dan Aplikasinya", Malang: Media Nusa Creative

Yasin, A., \& Lisdawati, L. (2017). Evaluasi Penyusunan Program Kerja Komite Sekolah: Upaya Peningkatan Partisipasi Masyarakat dan Mutu Pendidikan di SMP Negeri I Sungai Pakning. Sosial Budaya, 13(2), 162175. 